Piotr Roman Gryziec OFMConv.

\title{
Formuła konsekracji eucharystycznej - zapowiedź czy anamneza?
}

Od wieków Kościół katolicki celebruje Eucharystię jako pamiątkę ostatniej wieczerzy, a jednocześnie ofiary złożonej na krzyżu przez Jezusa. Podstawą tego aktu liturgicznego są słowa Jezusa zapisane przez św. Pawła (1 Kor 11, 24. 25) oraz przez św. Łukasza (Łk 22, 19c): „To czyńcie

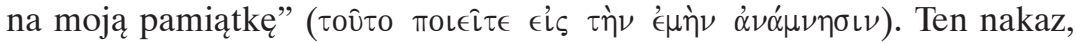
który zdaniem niektórych egzegetów pochodzi z tzw. tradycji antiocheńskiej $^{1}$, stał się podstawą do wytworzenia się liturgii, która miała za zadanie uobecniać wydarzenia paschalne ${ }^{2}$. Zaimek wskazujący „to” ( powszechnej interpretacji teologicznej dotyczy zarówno gestów zapisanych w przekazach nowotestamentowych, jak i słów wypowiedzianych przez Jezusa nad chlebem i nad kielichem. Słowa te według utrwalonej i uprawomocnionej od wieków rzymskiej formuły liturgicznej brzmią: „Hoc est enim corpus meum, quod pro vobis tradetur” oraz: „Hic est enim calix sanguinis mei novi et aeterni testamenti, qui pro vobis et pro multis effundetur in remissionem peccatorum"3.

Powyższe formuły są adaptacją słów, jakie zostały przekazane Kościołowi przez autorów natchnionych. Przede wszystkim takiej wersji, jaka występuje w Mszale rzymskim, nie spotkamy w żadnym świadectwie Nowego Testamentu. Każdy autor biblijny podaje inną wersję słów Jezusa, jednak żadna z tych

${ }^{1}$ Oprócz tradycji antiocheńskiej zwanej także hellenistyczną lub Pawłową przekazy NT zawierają także tradycję palestyńską, inaczej Piotrową, reprezentowaną przez Ewangelie Marka i Mateusza - por. A. JANKOwski, Biblijna teologia przymierza, Kraków 1997, s. 106. H. SchÜRmanN, Stowa Jezusa przy Ostatniej Wieczerzy, „Concilium. Międzynarodowy Przegląd Teologiczny” 1-10 (1968), Poznań-Warszawa 1969, s. 592, p. 13, twierdzi, że to właśnie czynności relacjonowane przez Pawła wykazują charakterystyczne znamiona pochodzenia palestyńskiego.

${ }^{2}$ Por. Katechizm Kościoła Katolickiego, 1353: „W opisie ustanowienia Eucharystii moc słów i działania Chrystusa oraz moc Ducha Świętego sprawia, że pod postaciami chleba i wina uobecnia się sakramentalnie Ciało i Krew Chrystusa, Jego ofiara złożona na krzyżu raz na zawsze".

${ }^{3}$ Taka forma została zachowana także w najnowszej wersji Missale romanum promulgowanego w roku 2000. 
wersji nie odpowiada dokładnie wersji zastosowanej w liturgii ${ }^{4}$. Skoro jednak pewne istotne elementy formuły konsekracyjnej występują w każdym z nowotestamentowych przekazów, należy je odnieść do samego Jezusa. Słowa wypowiadane nad chlebem podczas mszy świętej najbardziej przypominają wersję zapisaną w Ewangelii Łukasza, która brzmi w przekładzie Nowej

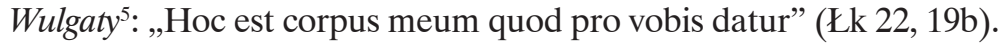

Różnica pomiędzy tekstem biblijnym a zatwierdzonym tekstem liturgicznym nie jest li tylko kosmetyczna. Pomijając fakt użycia innego czasownika (zamiana „dare” na „tradere”), zwróćmy uwagę, że w łacińskim tekście biblijnym (zgodnie zresztą z greckim oryginałem) został użyty czas praesens, natomiast w tekście liturgii rzymskiej futurum. Do tego zagadnienia powrócimy w dalszej części artykułu, teraz chcieliśmy zasygnalizować tylko tę różnicę, ponieważ ma ona doniosłe konsekwencje dla teologii Eucharystii.

Formuła konsekracyjna wypowiadana nad kielichem zredagowana została na bazie przekazu św. Mateusza i uzupełniona w oparciu o przekaz Łukaszowy. Wersja Mateuszowa w tekście łacińskim Nowej Wulgaty brzmi: „Hic est enim sanguis meus novi testamenti qui pro multis effunditur in remissionem peccatorum” (Mt 26, 28) ${ }^{6}$.

Od Łukasza pochodzą dodatki „calix” oraz „pro vobis”. Najistotniejszą różnicą w stosunku do tekstu biblijnego jest, podobnie jak w pierwszym przypadku, zmiana czasu czasownika „effundere” z praesens na futurum. Do tej pory nie odnosiłem się do tekstu greckiego, lecz do tekstu Nowej Wulgaty z tej prostej przyczyny, że właśnie ten tekst został oficjalnie usankcjonowany przez Stolicę Apostolską jako podstawa dla wszelkich ksiąg liturgicznych (sic!).

Wydawać by się mogło, że zmiana czasu praesens na futurum wyraża lepiej historyczny kontekst wydarzeń, jakie miały miejsce podczas ostatniej wieczerzy. W chwili, w której Jezus wypowiadał słowa konsekracji, Jego Ciało jeszcze nie było „wydane”, a Krew nie była jeszcze „przelana”. W czasie uczty paschalnej Jezus zapowiedział to, co miało się stać niebawem na Kalwarii ${ }^{8}$. Tak rzecz może być widziana z historycznego punktu widzenia. Jednak w Eucharystii nie chodzi o „historię”, tzn. o przytoczenie słów i wydarzeń, jakie miały miejsce, lecz o „anamnezę”. Misterium

\footnotetext{
${ }^{4}$ Trzeba jednak zaznaczyć, że cztery opowiadania zawarte w NT są już liturgiczną adaptacją słów i czynów Jezusa z ostatniej wieczerzy, stąd trudność uzgodnienia ich oryginalnego brzmienia - por. J. E. Kilmartin, Ostatnia Wieczerza i najwcześniejsze ofiary eucharystyczne, „Concilium. Międzynarodowy Przegląd Teologiczny” 1-10 (1968), Poznań-Warszawa 1969, s. 562.

${ }^{5}$ Nova Vulgata Bibliorum Sacrorum editio, Sacros. Oecum. Concilii Vaticani II ratione habita, iussu Pauli PP. VI recognita, auctoritate Ioannis Pauli PP. II promulgata, Romae 1979.

${ }^{6}$ Cytat za: Novum Testamentum latine, ed. K. Aland et B. Aland, Stuttgart ${ }^{2} 1992$.

${ }^{7}$ Dodatek „et aeterni” jest uprawomocniony na podstawie Hbr 7, 25-27; 10, 10. 14.

${ }^{8}$ Por. J. Drozd, Ostatnia Wieczerza nowa Pascha, Katowice 1977, s. 158n.
} 
zbawienia to nie tylko historia, ale i teraźniejszość. Jezus nie powiedział apostołom: „Opowiadajcie, co miało teraz miejsce”, lecz: „Czyńcie to jako

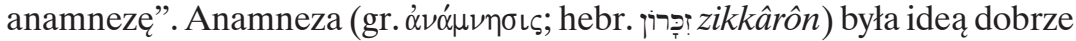
znaną w kulcie Starego Testamentu, dlatego apostołowie musieli właściwie zrozumieć słowa Jezusa ${ }^{9}$. Zaczniemy zatem od przybliżenia rozumienia anamnezy, jaka ma miejsce podczas Eucharystii.

\section{Istota anamnezy eucharystycznej}

Aby jaśniej ukazać problem, który będzie przedmiotem dalszych rozważań, musimy zdefiniować pojęcie „anamneza”. Anamnezę w rozumieniu teologicznym określa się jako „uroczyste uobecnienie jakiegoś historycznego wydarzenia zbawczego, aby mogło ono zawładnąć sytuacją uczestnika uroczystości. Zakłada się zatem, że chodzi o wydarzenie historyczne jednorazowe, które zachowując tę jednorazowość jest zarazem teraźniejszością, i że człowiek sam w swoim własnym czasie może uobecnić teraźniejszość owego wydarzenia"10. Anamneza skupia w sobie potrójną funkcję:
a. wspominanie faktu, jaki zaistniał w przeszłości,
b. uobecnienie tego faktu w teraźniejszości,
c. ukierunkowanie na przyszłość eschatologiczną ${ }^{11}$.

Uobecnionym wydarzeniem w przypadku Eucharystii jest nie tylko uczta paschalna, ale także i przede wszystkim śmierć na krzyżu, dlatego w Eucharystii te dwa wydarzenia nakładają się na siebie i są przeżywane równocześnie. W nakazie: „To czyńcie na moją pamiątkę” (1 Kor 11, 25) termin $\dot{\alpha} \nu \alpha \dot{\alpha} \mu \nu \eta \sigma \varsigma \varsigma$ umieszczony został na końcu frazy, na pozycji emfatycz$n^{12}{ }^{12}$. Po takim wyeksponowaniu terminu zostaje wyjaśniona jego treść w kolejnym zdaniu połączonym z poprzednim spójnikiem „bowiem” ( $\gamma \alpha \dot{\alpha} \rho)$ : „Ilekroć bowiem spożywacie ten chleb i pijecie kielich ${ }^{13}$, śmierć Pana

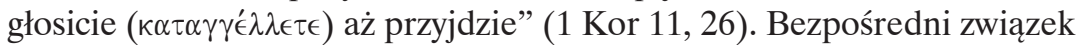
tego wyjaśnienia ze słowami: „To czyńcie na moją pamiątkę” został wyakcentowany w liturgii eucharystycznej w słowach drugiej aklamacji po przeistoczeniu: „Ile razy ten chleb spożywamy i pijemy z tego kielicha, głosimy śmierć Twoją Panie, oczekując Twego przyjścia w chwale”. Czasow-

${ }^{9}$ Więcej na temat anamnezy w ST pisze A. JANKowski, Biblijna teologia przymierza, dz. cyt., s. 111-114.

${ }^{10}$ K. Rahner, H. Vorgrimler, Mały stownik teologiczny, przeł. T. Mieszkowski, P. Pachciarek, Warszawa 1987, s. 10.

${ }^{11}$ Por. R. GoczoŁ, Anamneza, [w:] Encyklopedia katolicka, red. F. Gryglewicz, R. Łukaszyk, Z. Sułowski, t. 1, Lublin 1973, s. 511.

${ }^{12}$ Por. A. Jankowski, Biblijna teologia przymierza, dz. cyt., s. 116.

${ }^{13}$ Metonimia, w której słowo kielich zastępuje jego zawartość. 
nik к $\alpha \tau \alpha \gamma \gamma \in \hat{\epsilon} \lambda \lambda \omega \mathrm{w}$ Nowym Testamencie ${ }^{14}$ ma zawsze sens sakralny. Określa on uroczystą proklamację samego Jezusa, zwłaszcza zmartwychwstałego Pana, zawierającą w sobie dramatyczno-eschatologiczny wymiar zbawczego orędzia ${ }^{15}$. Tego rodzaju „głoszenie” przekazuje słuchaczom zbawcze owoce wydarzenia, które jest treścią orędzia. Poprzez wspólnotę zebranego Kościoła działa sam Bóg, który sprawia, że jednorazowe wydarzenie wywołuje ciągle nowe skutki ${ }^{16}$. Zaś zbawcze owoce nie są możliwe, dopóki nie nastąpi śmierć Jezusa. Dlatego po momencie uobecnienia śmierci Jezusa, której zbawcza moc zostaje dopełniona przez zmartwychwstanie, celebrans wypowiada słowa: „Wspominając (tj. „czyniąc anamnezę”) śmierć i zmartwychwstanie Twojego Syna, ofiarujemy Tobie, Boże Ojcze, Chleb życia i kielich zbawienia..." (druga modlitwa eucharystyczna).

Św. Paweł pisząc z perspektywy dokonanych wydarzeń paschalnych, niewątpliwie rozumiał, że już w momencie spożywania chleb i wino są Ciałem wydanym i Krwią Chrystusa przelaną za nas (por. 1 Kor 11, 26). Taka sama musiała być również intencja Jezusa ustanawiającego Eucharystię. „Pawłowi zawdzięczamy swoistą eksplicytację intencji samego Jezusa, a zarazem cenne połączenie krwawej żertwy Wielkiego Piątku z Eucharystią Wielkiego Czwartku"17. A zatem anamneza, jaką nakazał sprawować uczniom Jezus podczas Ostatniej Wieczerzy, zapowiadając swoją bliską śmierć, ma być liturgicznym uobecnieniem Jego ofiary. Nowa Pascha, jaka jest Eucharystia, jest „pamiątką" już pełnego odkupienia ${ }^{18}$. Jan Paweł II przypomina tę prawdę, pisząc w swojej encyklice Ecclesia de Eucharistia, że Eucharystia „zawiera niezatarty zapis męki i śmierci Pana. Nie jest tylko przywołaniem tego wydarzenia, lecz jego sakramentalnym uobecnieniem. Jest ofiarą Krzyża, która trwa na wieki” (nr 11). Jeszcze wyraźniej obecność ofiary Chrystusa w momencie przeistoczenia wyraża następny punkt encykliki, gdzie papież pisze, że Zbawiciel ustanawiając Eucharystię „nie potwierdził jedynie, że to, co im [apostołom] dawał do jedzenia i picia, było Jego Ciałem i Jego Krwią, lecz jasno wyraził, że ma to wartość ofiarniczą, czyniąc obecną w sposób sakramentalny swoją ofiarę, która niedługo potem miała dokonać się na krzyżu dla zbawienia wszystkich" (nr 12).

Jak pisze J. E. Kilmartin, ,przez chleb i wino, które są teraz ciałem i krwią, Jezus przekazuje uczniom [...] udział w błogosławieństwie wypływającym

${ }^{14}$ Występuje tylko w Dz (11 razy) i w pismach Pawłowych (7 razy).

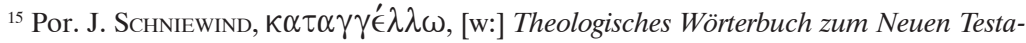
ment, hrsg. von G. Kittel, t. 1, Stuttgart 1957, s. 69-71.

${ }^{16}$ Por. J. Drozd, Ostatnia Wieczerza, dz. cyt., s. 169.

${ }^{17}$ A. Jankowski, Biblijna teologia przymierza, dz. cyt., s. 116.

${ }^{18}$ Por. tamże, s. 114. 
$\mathrm{z}$ „wydanego ciała” $\mathrm{i}$,wylanej krwi”, a tym błogosławieństwem jest uwolnienie $\mathrm{z}$ władzy grzechu i nawiązanie nowego przymierza z Bogiem." ${ }^{\prime 19}$

\section{Słowa wypowiadane nad chlebem}

W Nowym Testamencie spotykamy cztery przekazy słów wypowiedzianych przez Jezusa nad chlebem. Stanowią one wczesnochrześcijańską liturgiczną adaptację tych słów ${ }^{20}$ ukształtowaną w postaci dwóch odrębnych tradycji. Najstarszym dokumentem, który zawiera przekaz ustanowienia Eucharystii, jest Pierwszy List do Koryntian. Z tej samej tradycji, co Paweł, korzystał także Łukasz. Marek, a za nim Mateusz odzwierciedlają inną tradycję:

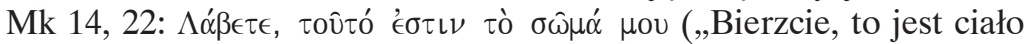
moje");

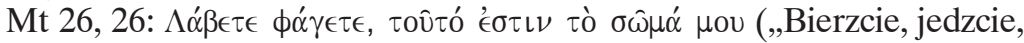
to jest ciało moje").

Przytoczone świadectwa nie zawierają wzmianki o „wydaniu”. Jedynym

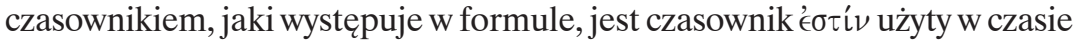
teraźniejszym. Taka forma przekazu nie ma żadnego bezpośredniego odniesienia do ofiary, wyraża jedynie fakt przeistoczenia chleba w Ciało Chrystusa. Jednak łatwo wytłumaczyć ten brak dookreślenia wskazującego na czynność ofiarniczą faktem połączenia ze sobą dwóch czynności oraz dwóch wypowiedzi związanych z chlebem i z kielichem w procesie kształtowania się liturgii pierwotnego Kościoła ${ }^{21}$. W trakcie wieczerzy paschalnej te dwie czynności były od siebie oddzielone w czasie: chleb łamano na początku uczty, natomiast „kielich błogosławieństwa” był podawany na jej zakończenie. Marek wykorzystał wczesną tradycję liturgiczną, która te dwa momenty już połączyła razem.

Inaczej przedstawia się wersja Pawłowo-Łukaszowa, która zawiera istotne dopowiedzenie:

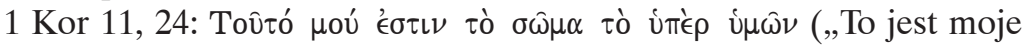
ciało za was");

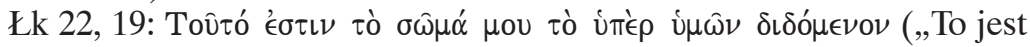
ciało moje za was [wy]dane") ${ }^{22}$.

${ }^{19}$ J. E. Kilmartin, Ostatnia Wieczerza i najwcześniejsze ofiary, art. cyt., s. 565.

${ }^{20}$ Por. H. Schürmann, Stowa Jezusa, dz. cyt., s. 590.

${ }^{21}$ Por. J. Jeremias, Die Abendmahlworte Jesu, Göttingen 1966, s. 20-23; H. Schürmann, Stowa Jezusa, dz. cyt., s. 591.

${ }^{22}$ Czasownik $\delta i ́ \delta \omega \mu \iota$, który tłumaczy się zazwyczaj jako „dawać”, w Iz 53, 10 występuje w znaczeniu ofiarniczo-ekspiacyjnym, co jest dowodem na bardzo wczesne łączenie ofiary Jezusa z wypełnieniem proroctwa o Słudze Jahwe - por. A. JANKowski, Biblijna teologia przymierza, dz. cyt., s. 107. 
Taka wersja jest zrozumiała w sytuacji, kiedy obydwie czynności są od siebie oddalone w czasie. Dystans czasowy wymagał wypowiedzenia takich słów, które wyjaśniałyby precyzyjnie dokonany gest. Dlatego należy słusznie przypuszczaćéc ${ }^{23}$ że zapis Łukaszowo-Pawłowy jest starszy od tradycji Markowo-Mateuszowej, ponieważ odzwierciedla sytuację pierwotną - przed połączeniem obydwu formuł w jedną całość. Potwierdza to także fakt, że zarówno Łukasz, jak i Paweł zachowali w swych przekazach okolicznik czasu:

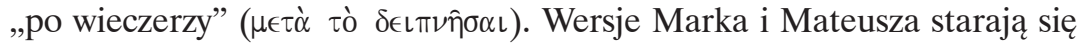
natomiast zharmonizować brzmienie słów nad chlebem i kielichem, traktując je jako paralelnie wypowiedziane zdania. H. Schürmann uważa, że Łukaszowa relacja jest oparta na najstarszej tradycji, którą także Paweł przejął i zmodyfikował ${ }^{24}$. Nie będę tutaj eksplikował tych modyfikacji, ponieważ nie wnoszą one istotnej zmiany w stosunku do rozpatrywanego zagadnienia.

Przyjmując wersję Łukaszową jako najbliższą oryginalnym słowom Jezusa, musimy mieć na uwadze, że Jezus wypowiedział je nie w języku greckim, lecz aramejskim. Jest to istotne ze względu na fakt, ze wielu komentatorów, analizując użyty przez Łukasza imiesłów czasu teraźniejszego $\delta\llcorner\delta o ́ \mu \in v o v$, zaznacza, że w języku greckim imiesłów czasu teraźniejszego (praesens) odnosi się zazwyczaj do czynności aktualnie wykonywanej, ale może także oznaczać czynność, która będzie wykonana w niedalekiej przyszłości ${ }^{25}$. Stąd wzięło się popularne w przekładach Nowego Testamentu na języki współczesne stwierdzenie: „które za was będzie wydane”26. Biorąc jednak pod uwagę fakt, że słowa te zostały wypowiedziane przez Jezusa po aramejsku, powyższe tłumaczenie traci na wartości. Należy przypuszczać, że Jezus w formule konsekracyjnej użył także imiesłowu, jednak w języku aramejskim (podobnie jak w hebrajskim) nie zachodzi dwuznaczność analogiczna do wyżej wspomnianej. Język aramejski (jak i hebrajski) nie rozróżnia czasów, tak jak język grecki, natomiast imiesłów posiada stronę czynną lub bierną i spełnia zazwyczaj rolę przymiotnika. Dlatego można z dużym prawdopodobieństwem założyć, że imiesłów ten w połączeniu z rzeczownikiem „ciało” tworzył syntagme „,ciało wydane”. Starotestamentowi prorocy posługiwali się czasem formą dokonaną czasownika (tzw. perfectum propheticum)

${ }^{23}$ Za H. Schürmannem, Stowa Jezusa, dz. cyt., s. 592.

${ }^{24}$ Dowody przedstawia autor w pracy Die Einsetzungsbericht Lk 22,19-20 (NeutestAb XX, 4), Münster 1955, s. 17-81; por. J. KudASIEwICZ, Teksty ustanowienia Eucharystii, [w:] Biblia o Eucharystii, red. S. Szymik, Lublin 1997, s. 65.

${ }^{25}$ Por. J. Drozd, Ostatnia Wieczerza, dz. cyt., s. 158; R. BARTnicki, Eucharystia w Bożym planie zbawienia, „Ruch Biblijny i Liturgiczny” 1 (1997), 15. H. WIтczYK, Pascha Jezusa odpowiedzia Boga na grzech świata, Lublin 2003, s. 255, zwraca przy tej okazji uwagę na fakt, że imiesłów czasu przyszłego niemal zanikł w grece Nowego Testamentu.

${ }^{26}$ Tak m.in. Biblia Tysiąclecia, Biblia Poznańska, polski przekład ekumeniczny NT. 
przepowiadając przyszłe wydarzenia ${ }^{27}$. Jezus, działając w nurcie tradycji prorockiej, mógł użyć takiego wyrażenia, ponieważ podczas ostatniej wieczerzy proroczo zapowiedział swoją śmierć, która dla Niego w momencie wypowiadania tych słów była faktem całkowicie pewnym.

Dodatkowym argumentem za „teraźniejszym” rozumieniem imiesłowu „wydane” jest - paradoksalnie - jego brak w formule z 1 Kor 11, 25. Słowa

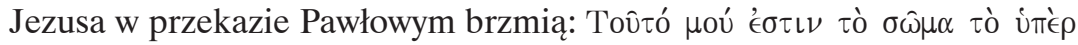
u $\mu \omega \hat{\nu}$ („To jest moje Ciało za was”). Taka wersja formuły nie ma żadnego odniesienia do przyszłości. Według Pawła już sam przyimek ímé n nadaje „pamiątce” charakter ekspiacyjny ${ }^{28}$, natomiast Ciało Jezusa otrzymuje moc ekspiacji dopiero po śmierci, dlatego „pamiątka” musi obejmować także fakt śmierci. Nie można zatem mówić o anamnezie eucharystycznej bez dopełnionej ofiary Krzyża. J. E. Kilmartin wskazuje na istotne rozróżnienie: można mówić o sakramentalnej obecności Jezusa w czasie ostatniej wieczerzy pod postaciami chleba i wina, których spożywanie było udziałem w owocach zbawienia „przez antycypacje”, ale „nie możemy mieszać pojęcia takiej sakramentalnej obecności z inną, która nastąpiła po zmartwychwstaniu, gdy Pan chwalebny, nie ograniczony czasem i przestrzenią przychodzi pod postacią chleba i wina"29.

\section{Słowa wypowiedziane nad kielichem}

W przypadku słów wypowiedzianych nad kielichem obydwie tradycje zgodnie przytaczają wzmiankę o przelanej krwi i jej związku z przymierzem.

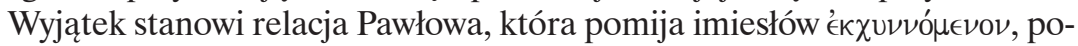
dobnie zresztą jak $\delta\llcorner\delta o ́ \mu \epsilon \nu o \nu$ w formule wypowiedzianej nad chlebem. Cztery wersje podaję według przypuszczalnej chronologii ewolucji tej formuły ${ }^{30}$ :

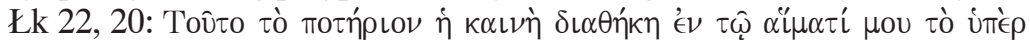

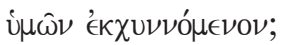

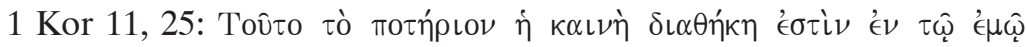
$\alpha i \mu \alpha \tau$;

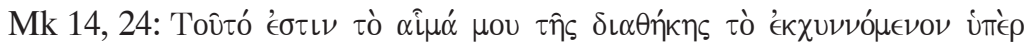
$\pi 0 \lambda \lambda \omega \bar{\omega} \nu$

${ }^{27}$ Por. P. JoüOn, T. MuraokA, A Grammar of Biblical Hebrew, Roma 1991, $\S 112 \mathrm{~h}$ (Subsidia Biblica, 14).

${ }^{28}$ Szeroko na temat przyimka úTé $\rho$ pisze H. WitCZYK, Pascha Jezusa, dz. cyt., s. 256265.

${ }^{29}$ J. E. Kilmartin, Ostatnia Wieczerza i najwcześniejsze ofiary, art. cyt., s. 565.

${ }^{30}$ Omawiając formułę nad chlebem, zaznaczyłem, że wersja Łukaszowa zachowuje najlepiej pierwotną tradycję. 


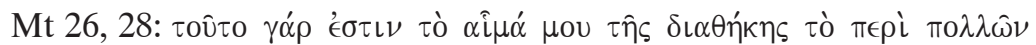

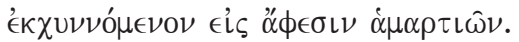

W obecnym opracowaniu nie będę zajmował się różnicami, jakie występują pomiędzy poszczególnymi zapisami. Na ten temat istnieje obfita literatura, która je obszernie interpretuje. Skoncentruję się jedynie na

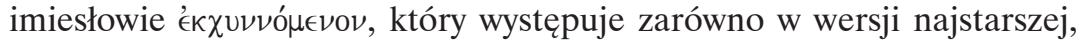
jak i najmłodszej. Sama wzmianka o krwi jest wystarczająca do wskazania na kontekst przymierza ( podkreślić także wymiar ekspiacyjno-ofiarniczy swojej Krwi. Czasownik

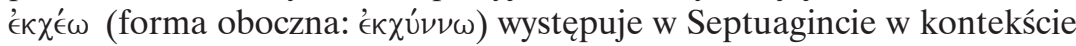
ofiarniczym (por. Kpł 4, 7. 18. 25.30.34; 8, 15; 9, 9). Krew wylana na ołtarz jest istotnym czynnikiem zadośćuczynienia, zwłaszcza w corocznym rytuale Dnia Przebłagania. Według Hbr 9, 22 ,bez rozlania krwi $(\alpha i \mu \alpha \tau \in \kappa \chi \cup \sigma i \alpha)$ nie ma odpuszczenia grzechów”, a przecież-jak zaświadcza zapis Mateuszowy - Jezus ofiarował siebie „na odpuszczenie grzechów” (Mt 26, 28c). „Znane równanie biblijne „krew = życie” $(K p ł 17,11.14)$ - pisze A. Jankowski - stanowi tu podtekst uzasadniający identyczność: Chrystus jest Nowym Przymierzem dzięki pełni ofiary z własnego życia"31.

Gdyby imiesłów czasu teraźniejszego interpretować w znaczeniu przyszłym, jak to czynią niektórzy egzegeci, sytuacja byłaby niespójna, ponieważ w mentalności żydowskiej już sam fakt oddzielenia krwi od ciała był synonimem śmierci, zgodnie z przekonaniem, że krew jest siedliskiem życia (por. Kpł 17, 11). A zatem nie może istnieć krew jako „oddzielona” od ciała przed śmiercią ofiary. Mówiąc „To jest moja Krew”, Jezus zakłada fakt jej przelania, antycypując za pomocą słów przyszłe wydarzenie, co nie było czymś wyjątkowym w przypadku słów wypowiadanych w biblijnych proroctwach. Zresztą jest oczywiste, że krew w kielichu jest odpowiednikiem krwi baranka paschalnego, skoro Paweł stwierdza, że „Chrystus został złożony w ofierze jako nasza Pascha” (1 Kor 5, 7b). W opisach ostatniej wieczerzy brak jest wzmianki o baranku, co wskazuje, że baranka paschalnego zastąpił łamany chleb i wino w kielichu. Wszystkie przytoczone wyżej racje, a także sposób konstrukcji wypowiedzi, w której

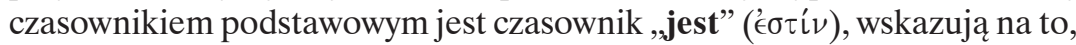
że Jezus chciał, aby rozumiano, że wino w kielichu jest krwią wylaną na odpuszczenie grzechów. W żadnej wersji słów konsekracyjnych nie występuje zaimek względny „która”, co dawałoby podstawę do wprowadzenia zdania podrzędnego: „która za was będzie wylana”. Jedyne orzeczenie

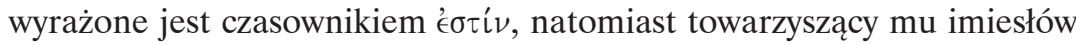
stanowi jedynie dookreślenie przymiotnikowe rzeczownika „krew” (istot-

${ }^{31}$ A. Jankowski, Biblijna teologia przymierza, dz. cyt., s. 134. 


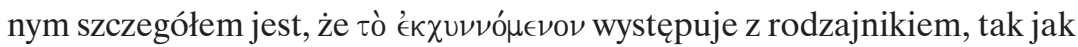
przymiotnik określający rzeczownik).

\section{Konkluzja}

Podsumowując przedstawione rozważania, należy stwierdzić, że większość tłumaczeń współczesnych oddaje tekst formuł wypowiedzianych podczas ostatniej wieczerzy, traktując je jako zwykłą zapowiedź mających nastąpić wkrótce wydarzeń. Takie tłumaczenia zostały również wykorzystane w tekstach liturgicznych ${ }^{32}$ do sprawowania Eucharystii. Tymczasem, jak to wskazuja gruntowne badania egzegetyczne ${ }^{33}$, wyraźną intencją Jezusa było uczynienie z wypowiadanych słów anamnezy własnej zbawczej śmierci i w takim sensie były one ustanowieniem Nowego Przymierza, które zgodnie $\mathrm{z}$ tradycją religijną Izraela wymagało przypieczętowania krwią ${ }^{34}$.

H. Witczyk zauważa ${ }^{35}$, że w odniesieniu do słów wypowiedzianych przez Jezusa w wieczerniku zachodzi podwójny kontekst znaczeniowy. Pierwszy to kontekst ustanowienia Eucharystii, w którym obydwie czynności dokonują się „teraz”, tak więc imiesłowy opisują rzeczywistość dokonującą się w momencie wypowiadania. Drugi kontekst stanowi historyczny moment samoofiarowania się Jezusa na krzyżu. Odniesione do tego momentu słowa opisują akt samoofiarowania się Jezusa jako sytuację, która zaistnieje w niedalekiej przyszłości, ale już jest proroczo uobecniana. Inna sytuacja

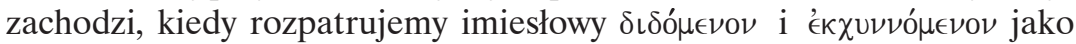
elementy liturgii Eucharystii sprawowanej jako „pamiątka” ( $\left.\alpha \alpha_{\alpha} \mu \nu \eta \sigma \iota \varsigma\right)$ we wspólnocie pierwotnego Kościoła. Sakrament Ciała i Krwi sprawowany przez Kościół jest pamiątką, czyli rzeczywistym uobecnieniem śmierci Chrystusa na Kalwarii jako eschatologicznej ofiary ekspiacyjnej ${ }^{36}$. „Imiesłowy te - na mocy polecenia Jezusa: «To czyńcie na moją pamiątkę» - wypowiadane w czasie Kościoła, opisują ten sam istotny związek między samoofiarowaniem się Jezusa w swoim Ciele i Krwi «teraz» (w Kościele), a Jego samoofiarowaniem się w przeszłości, na Kalwarii, taki sam jak związek między Ofiarą uobecnianą przez samego Jezusa w czasie Ostatniej Wieczerzy a Ofiarą na krzyżu" ${ }^{37}$.

${ }^{32}$ Zarówno w tekście łacińskim, jak i większości języków europejskich. Istnieją wyjątki, które będą wspomniane w dalszej części podsumowania.

${ }^{33}$ Przede wszystkim cytowana kilkakrotnie obszerna monografia H. WiтczYKA, Pascha Jezusa odpowiedzia Boga na grzech świata, Lublin 2003.

${ }^{34}$ Por. Hbr 9, 11-22.

${ }^{35}$ H. Witczyк, Pascha Jezusa, dz. cyt., 255.

${ }^{36}$ Tamże.

${ }^{37}$ Tamże. 
Jeżeli zatem „Eucharystia, aktualizując zbawienie dokonane przez Chrystusa, wprowadza uczestników w dzieło zbawcze dokonane raz dla wszystkich ludzi wszystkich czasów"38, to wydaje się słusznym, aby tę ponadczasowość i zarazem aktualność ofiary Jezusa wyrazić - zgodnie zresztą z przekazem Nowego Testamentu - czasem teraźniejszym, tym bardziej że i tak pierwsza

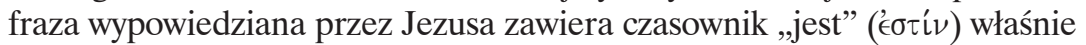
w tym czasie. Pozostaje do rozstrzygnięcia jeszcze jedna kwestia natury morfologicznej: omawiane imiesłowy reprezentują stronę medio-pasywną czasu praesens. Wierne ich tłumaczenie dopuszczałoby zatem dwie możliwości: „wydawane” lub „wydające się” (ciało) oraz „wylewana” lub „wylewająca się” $(\mathrm{krew})^{39}$. Takiego rozróżnienia nie spotkamy jednak w językach semickich; ponadto odniesienie się do mentalności semickiej Jezusa każe widzieć w wypowiadanych słowach ich niezawodną skuteczność. Czas praesens w języku greckim może wyrażać czynność trwającą lub ciągle powtarzaną. Użycie w thumaczeniu formy niedokonanej czasownika („wydawane”, „wylewana”) mogłoby sugerować powtarzalność ofiary Jezusa, a ta przecież została złożona jeden raz na zawsze (por. Hbr 9, 2; 10, 14). Aby nie suponować powtarzalności i zarazem oddać teologiczny sens ofiary Chrystusa, najlepiej użyć formy dokonanej (wszak ofiara się dokonała raz na zawsze) imiesłowu biernego w połączeniu z czasownikiem w czasie teraźniejszym ,jest”.

Postulatem wynikającym z przedstawionych rozważań - nie tylko egzegetycznym, ale i teologicznym, a przede wszystkim liturgicznym - jest wprowadzenie do formuł eucharystycznych tłumaczeń: „Ciało wydane” zamiast „Ciało, które będzie wydane” oraz „Krew wylana” w miejsce „Krwi, która będzie wylana”40. Zarówno biblijny, jak i liturgiczny zapis słów Jezusa jest bowiem anamnezą dokonanej zbawczej Ofiary, a nie tylko zapowiedzią wydarzeń Kalwarii.

Kraków

PIOTR GRYZIEC OFMCONv.

${ }^{38}$ J. KudAsiewicz, Teksty ustanowienia Eucharystii, art. cyt., 75.

${ }^{39}$ Określenia „krew wylewana” użył w swoim tłumaczeniu Mt 26, 28 i Mk 14, 24 R. PoPOwski, Nowy Testament. Przekład na Wieki Jubileusz Roku 2000, Warszawa 2000; inaczej w Łk 22, 20: „kielich, który się za was wylewa”, choć w tekście oryginalnym wszystkie wersje zawierają identyczną formę. Niekonsekwencje w tłumaczeniu występują także w najnowszym przekładzie polskim Nowy Testament i Psalmy, wydawnictwo św. Paweł, Częstochowa 2005, według którego ciało ,,jest wydane”, natomiast krew ,,jest wylewana” (Mt 26, 28; Łk 22, 20) lub „wylewa się” (Mk 14, 24). Strona zwrotna czasu teraźniejszego została zastosowana m.in. w mszale w języku słowackim oraz w rosyjskim i białoruskim.

${ }^{40} \mathrm{~W}$ tym miejscu warto zacytować zdanie znajdujące się w liście Episkopatu Polski na Rok Eucharystyczny Eucharystia źródłem i szczytem życia i misji Kościoła z 22 X 2004: „Właśnie podczas tej wieczerzy Jezus dając uczniom chleb i wino, mówi To jest Ciało moje za was wydane i to jest Krew moja za was przelana". 


\section{Sommario}

La formula di consacrazione eucaristica - preannunziazione o anamnesi?

Larticolo presente tratta della traduzione delle parole di consacrazione eucaristica. Nel Missale romanum latino hanno usato il tempo futuro: "tradetur" (riguardo al Corpo) ed "effundetur" (riguardo al Sangue), mentre nel testo greco del Nuovo Testamento si trovano i due

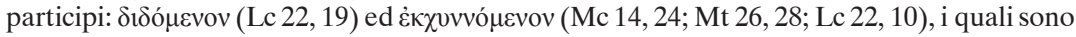
le forme del presente, perciò la Nuova Vulgata li traduce: "datur" ed "effunditur" ("funditur"). Il participium praesentis nel greco koine fu usato infatti anche nel senso futuro, esprimendo il fatto del futuro prossimo, però nel nostro caso le parole di Gesù non intendono informare sul futuro, ma assumono il carattere di un'anamnesi liturgica, attualizzando il sacrificio del Calvario (cfr. 1 Cor 11, 26: "annunciate la morte del Signore"), senza il quale il Corpo e il Sangue di Cristo non avrebbe il valore d'espiazione salvifica.

Il postulato che risulta dalla dimostrazione esposta nell'articolo è applicare nei testi liturgici eucaristici i sintagmi: "il Corpo offerto" al posto di "il Corpo che sarà offerto" e "il Sangue versato" al posto di "il Sangue che sarà versato" (parimenti al missale nella lingua italiana). Le parole di Gesù scritte nel Nuovo Testamento sono infatti un'anamnesi del sacrificio salvifico, non soltanto una preannunziazione dei prossimi eventi. 


\title{
NOWOŚć!
}

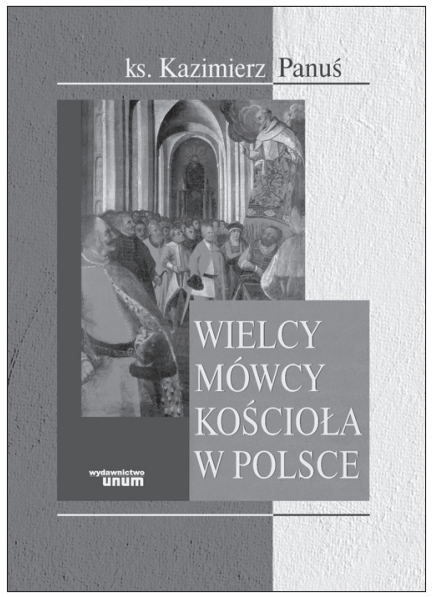

ks. Kazimierz Panuś

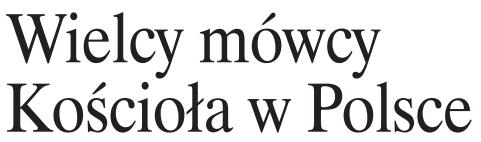

\author{
488 stron $\cdot$ format $16,5 \times 23,5 \mathrm{~mm}$ \\ oprawa twarda $\cdot$ cena 32 zł
}

Podejmując lekturę tej książki czytelnik zanurza się w fascynującą przygodę ukazującą stopniowe rozrastanie się ewangelii Chrystusowej i jej zakorzenianie na polskiej ziemi poprzez posługę głoszenia słowa Bożego. W uroczystym pochodzie przesuwają się sylwetki mistrzów polskiej ambony, poczynając od pierwszych kaznodziejskich dzieł Peregryna z Opola OP i ks. Stanisława ze Skarbimierza, poprzez wspaniały rozwój wymowy w XVI i XVII wieku, czego doskonałą ilustracją jest kaznodziejstwo ks. Stanisława Sokołowskiego, Piotra Skargi SI, Fabiana Birkowskiego OP, Tomasza Młodzianowskiego SI, Andrzeja Kochanowskiego OCD i Franciszka Rychłowskiego OFM, poprzez kaznodziejów XVIII- i XIXwiecznych takich, jak: Samuel Wysocki SchP, Sebastian Lachowski SI, bp Franciszek Karpowicz, abp Jan Paweł Woronicz, Karol Antoniewicz SI, Hieronim Kajsiewicz CR, św. bp Józef Sebastian Pelczar i ks. Władysław Chotkowski, aż po wielkich XX-wiecznych mistrzów polskiej ambony, wpierw z okresu międzywojennego, jak abp Antoni Szlagowski i abp Józef Teodorowicz, a potem z drugiej połowy XX wieku. W tej grupie spotkać można kapłanów takich, jak: Tadeusz Olszański CM, ks. Jan Zieja i ks. Julian Michalec oraz wielkich pasterzy narodu polskiego takich, jak: bp Jan Pietraszko, abp Jerzy Ablewicz, kard. Stefan Wyszyński, Prymas Tysiąclecia, a przede wszystkim kard. Karol Wojtyła Ojciec Święty Jan Paweł II. Wszyscy oni przynależą do panteonu narodowego kaznodziejstwa, a ich dokonania są klejnotami pierwszej wielkości w skarbnicy narodowej kultury. Oddając do rąk czytelnika niniejszy tom, autor żywi nadzieję, iż to spojrzenie na 25 wielkich mówców Kościoła w Polsce przyczyni się do głębszego zrozumienia istoty i roli kaznodziejstwa, do jego umiłowania i prowadzenia dalszych nad nim badań. Każde spotkanie z mistrzem polskiej ambony otwiera reprodukcja jego wizerunku lub ilustracja nawiązująca do jego osoby (herb zgromadzenia, kościół, w którym wygłaszał swoje kazania), a wieńczy przytoczony w całości charakterystyczny jego tekst kaznodziejski. Książka ta jest dobrą popularyzacją wiedzy o polskich kaznodziejach, a nie „ciężkim” dziełem naukowym, dlatego też najistotniejsze wskazówki bibliograficzne zamieszczono na końcu publikacji.

\section{Zamówienia}

Wydawnictwo UNUM · ul. Kanonicza 3 · 31-002 Kraków tel. (12) $4225690 \cdot$ e-mail: unum@ptt.net.pl Koszt przesyłki ponosi wydawnictwo. 